\title{
EXPLORING THE INTERACTION EQUATION: VALIDATING A RUBRIC TO ASSESS AND ENCOURAGE INTERACTION IN DISTANCE COURSES
}

\author{
M. D. Roblyer \\ University of Maryland University College \\ 300 Hidden Lakes Drive \\ Carrollton, Georgia 30116 \\ Telephone: (770) 838-0003 \\ Email: mroblyer@polaris.umuc.edu \\ W. R. Wiencke \\ University of West Georgia \\ College of Education \\ Carrollton, Georgia 30118 \\ Telephone: (770) 836-4436 \\ Email: wwiencke@westga.edu
}

\begin{abstract}
The degree of interaction among participants in distance courses is widely acknowledged to be an indicator of successful learning experiences; interaction has been found to contribute to both achievement and student satisfaction. As an increasing number of distance courses move to a completely asynchronous, online format, providing for better interaction is an important means of assuring course quality. To allow measurement and study of interaction in online courses, five elements were identified that contribute to interaction, and a rubric was designed to assess the degree of each in distance courses [1]. A previous use of the rubric in one online class [1] indicated the instrument had good convergent and divergent validity and reliability in terms of consistency of results across students. The current study focused on establishing the rubric's concurrent validity and consistency of results across four distance courses. Recommendations are made to increase the usefulness and reliability of the rubric in practice.
\end{abstract}

\section{KEYWORDS}

interaction, online course quality, rubric validity, rubric reliability

\section{INTRODUCTION}

Substantial distance learning theory and research has focused on the role of interaction in successful distance learning courses [2, 3, 4, 5, 6, 7]. Findings indicate that increased interaction in distance courses is associated with higher achievement and student satisfaction [8, 9, 10, 11]. For example, Swan [11] found that two of the three course design factors that contributed significantly to student satisfaction and perceived learning in online courses were related to instructor and student interaction. Although distance 
learning continues to increase in popularity, and course offerings abound [12], critics of distance learning express doubts that instructors separated by distance from their students can provide the same quality of education as in face-to-face courses [13]. Providing for high interaction among participants in distance courses is a key way to address these criticisms and assure equivalent quality for distance offerings.

Zhang and Fulford [9] offered evidence that interaction is a psychological construct, rather than a technological one, finding that number of completed messages or actual time spent in messaging had little relation to students' perceptions of the degree of interaction in an online course. An analysis of the literature on interaction in distance courses revealed that interaction is not one element, but several interrelated ones and is achieved "through a complex interplay of social, instructional, and technological variables" [1, p85]. From this analysis, five observable, measurable elements were derived that were seen as essential to the "interaction equation," i.e., indicators of qualities that determine interaction in distance courses:

1. social and rapport-building designs for interaction;

2. instructional designs for interaction;

3. interactive capabilities (interactivity) of the technologies used in the course;

4. evidence of learner engagement; and

5. evidence of instructor engagement.

To allow more meaningful examination of the role of interaction in enhancing achievement and student satisfaction in distance, these elements were used to develop a Rubric for Assessing Interactive Qualities in Distance Courses. This rubric was formulated and tested for use in distance learning environments in which an instructor is available to a specific group of students, rather than in courses set up for students to complete in a self-instructional manner. An initial use of the rubric in an online course revealed that it had good convergent/divergent validity, with rubric ratings diverging from course evaluations, as expected, only on the element that measured interactivity of technology resources being used in the course. Consistency across users also was high, with $95 \%$ of the students rating the course within four points out of the total 25 [1]. However, that study did not consider concurrent validity or traditional measures of inter-rater reliability for the rubric.

Since past research found a correlation between perceived high interaction in a course and course satisfaction [10], a measure of interaction in distance courses also should correlate highly with course evaluations. Thus, a rubric designed to measure interaction in distance courses should be found to demonstrate concurrent validity if it correlates with students' evaluations of the course. To explore this premise and further validate the usefulness of the rubric as a measure of course interaction, this study expanded the use of the rubric to additional courses and gathered data to indicate concurrent validity and inter-rater reliability.

\section{BACKGROUND LITERATURE AND THEORETICAL FRAMEWORK}

Much useful work has been done to define interaction as a construct and to identify a theoretical basis for the characteristics of interaction associated with distance learning. However, course design guidelines and subsequent impact research has not kept pace with theory and research. One reason for the lack of transfer from theory to practice in this area is the complex nature of interaction in distance courses and the difficulty of designing assessment and evaluation tools that build on a solid theoretical framework, yet provide sufficiently practical guidelines to make the concept of interaction measurable and useful to distance instructors and researchers. 
Jonassen, Peck, and Wilson [14] recommend rubrics as tools for assessing complex performance in a way that gives input and feedback to help improve the performance. Rubrics, which consist of a set of elements that describe a performance, together with a scale (e. g., 1-5 points) based on levels of performance for each element, have become increasingly popular in educational technology as a means of assessing the quality of complex tasks such as digital portfolios [15] and web page creation [16]. When these rubrics are combined with descriptions and examples of effective performances for each component quality, they become a powerful means to clarify expectations and guide performance. Although rubrics have been designed to assess the overall quality of online courses (e.g., see http://www.csuchico. edu/celt/roi/), the rubric described here marks the first time such an instrument has focused on quality of interaction in distance courses and has collected data to validate the instrument in practice.

Of the elements that were determined to reflect observable, measurable qualities of interaction to include in a rubric, two are those over which the instructor has control: designs for social interaction and designs for instructional interaction. A third element focused on interactive qualities of the technologies used in a distance course, while two other elements measure kinds and qualities of messages: learner engagement and instructor engagement. Articulating these elements and providing a scale to measure them is essential to permitting better, more comparable research on the hypothesis that higher interaction of one or more kinds leads to higher achievement and course satisfaction.

\section{A. Social and Rapport-Building Designs for Interaction}

Several distance-learning researchers have found that social interactions play a key part in increasing the total interaction of a distance course and can enhance and further learning. Picciano [17] notes that in non-online courses, students often learn from each other in many outside-class situations, sharing insights and information in social exchanges in the library or cafeteria. Since they cannot meet in this way in virtual courses, he says that online courses should be designed to simulate and promote this interaction.

Woolcott [18] says that increasing social rapport among participants helps decrease the "psychological distance" and isolation often experienced by distance students. She finds that decreasing psychological distance has the effect of increasing both motivation and observed interaction in the course and, thus, enhancing learning.

Vrasidas and McIsaac [4] say that students have a need to interact socially, as well as to learn, in a course setting, and Gilbert and Moore find that "social interaction can directly foster instructional interaction" [2, p31]. Activities designed to increase social rapport among course participants may help meet this need, as well as facilitate the learner-to-learner interaction that Moore [3] identifies as one of the essential types of interaction. The scale of interaction for this element ranges from very limited, one-time information exchanges of background information among students to ongoing course activities designed to encourage social and personal interactions. Although social interaction among students is the primary focus of this element, instructor participation is also a factor in decreasing psychological distance. In light of this, higher levels of interaction on this element include both activities designed to increase social rapport among students and instructor.

\section{B. Instructional Designs for Interaction}

Wagner [5] points out that instructional design theory and practice impact directly the kind and extent of interaction possible in a distance course. Highly interactive learning environments include specific activities that are designed to encourage, support, and even require interaction. Wagner [6] lists 13 
possible outcomes of these activities (e.g., interaction to increase participation, interaction to enhance learner control and self-regulation). These outcomes are especially helpful when viewed in the context of designs that enable collaboration among students and instructor as co-participants in the course, rather than only between the instructor and individual students.

Since Vrasidas and McIsaac [4] find that larger class sizes inhibit student-to-student interaction, distance course designers often cite collaborative learning strategies as a way to increase interaction among participants [19, 20, 21, 22, 23]. Small-group, collaborative designs not only require students to interact with each other, they also make frequent, meaningful interaction more manageable. Thus, the scale of interaction for this element ranges from designs that require simple, one-way delivery of information to individual students to those that maximize instructor-student exchanges and make possible collaborations within and among groups.

\section{Interactivity of Technology Resources}

Wagner [5] noted that technologies vary greatly in their potential to promote interaction. Thus, she differentiates between technology characteristics, which she refers to as "interactivity," and outcomes of using them, which she calls "interaction." While exploiting the potential of technologies depends on the instructional designs in which they are employed, Simonson, Smaldino, Albright, and Zvacek [24] feel that differences in technology characteristics impact critical learning variables such as types and immediacy of feedback mechanisms and methods of presenting and elaborating on information [5], as well as the amount and kind of collaboration techniques possible among participants of small groups. Horn says that "interactivity varies based on the transmission medium" [25, p15], and that "...absence of immediate feedback and nonverbal cues leads to unnecessary anxiety and hostility among students” [25, p13].

Since technologies that permit more visual cues, hypermedia presentations, and two-way, more immediate communications are also assumed to permit higher interactivity than those that allow only written or audio messages and one-way communications, the rubric scale focuses on the range of these qualities. However, it is important to emphasize again that levels of technological interactivity are only potential contributors to interaction. They become meaningful components to promote interaction only in the context of course designs that take full advantage of them.

\section{Evidence of Student Engagement}

Distance course designers acknowledge that instructors share responsibility with students to promote interactive learning in online learning communities [26, 27]. Moore and Kearsley [28] emphasize that instructors can create an environment conducive to high interaction and learner autonomy. Hillman, Willis, and Gunawardena [29] propose that instructors must give students assistance and practice to increase the likelihood of successful use of technologies that allow interaction. However, student response to these requirements and efforts is variable. Although student engagement can vary considerably, despite the instructor's efforts to encourage it, it nonetheless has an impact on the total interaction possible in a distance course. Vrasidas and McIsaac [4] and Brown [30] found that less experienced distance learners participated less frequently and less spontaneously, either for social or instructional purposes. The more comfortable the students are with distance formats, the more likely they are to interact. Roblyer [31] found high student engagement was characterized by voluntary, as well as required, messages that were responsive to the purpose of the discussion. In the rubric, the range of interaction as reflected in student engagement considers three different qualities: required versus voluntary responses, responding versus initiating messages, and the quality of constructed responses. 


\section{E. Evidence of Instructor Engagement}

As noted previously, Zhang and Fulford [9] illustrated that students' perceptions of interaction in a distance-learning course do not correlate with actual interaction (number of messages, time spent interacting). Rather, perceptions seem shaped by quality and usefulness of interaction. Yacci [7] characterized interaction as a psychological construct influenced both by lag time and coherence (i.e. perceived instructional value) of responses. Kearsley [26] and Simonson and colleagues [24] also find that instructors can either enhance or decrease course interaction depending on how consistently, quickly, and helpfully they respond. As noted previously, Swan [11] found that the most successful online courses are those in which instructor-to-student interaction is both frequent and productive. Thus, evidence of high instructor engagement in the rubric ranges from low to high in the quality, speed, and usefulness of feedback to students.

\section{F. Summary of Elements in the Interaction Equation}

These findings indicated that instructors, learners, and technologies are all essential parts of the interaction equation. The interrelationship among these factors in a distance course is shown in Figure 1.This figure depicts interaction as "a created environment in which social and instructional messages are exchanged among entities of a course, and in which messages are both carried and influenced by the activities and technology resources” [1, p81].

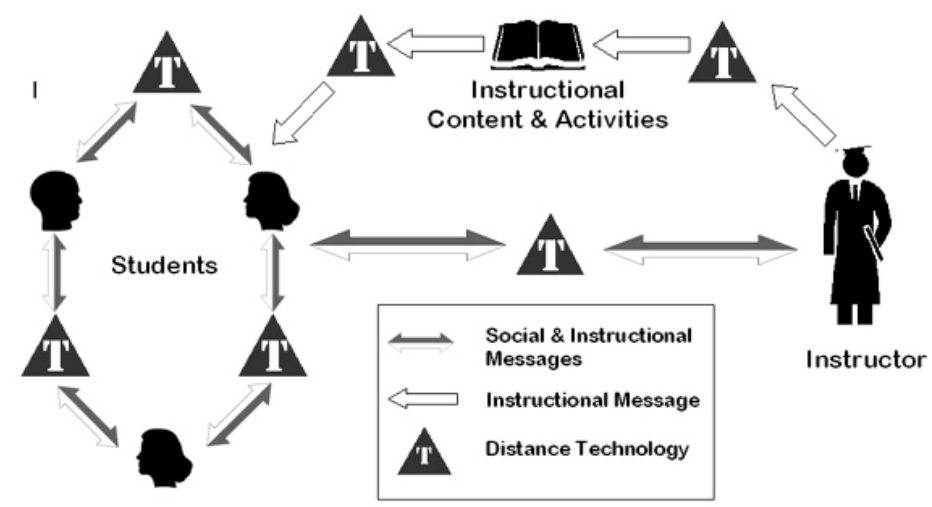

Figure 1. Model of Interaction in a Distance Course Environment

\section{STUDY METHODS AND DATA SOURCES}

Although methods of establishing reliability and validity of rubrics are relatively new, several strategies have been used in recent years. Taggart, Phifer, Nixon, \& Wood [32], recommend improving rubric content validity by involving instructors in its development and helping to ensure reliability by training raters. In studies to validate rubrics to assess student writing samples, Baker and Abedi [33] and Novak, Herman, and Gearhart [34] used a variety of methods, including establishing concurrent validity by correlating rubric scores to other measures of writing performance and obtaining an indication of interrater reliability with the "classical techniques" [34] of calculating alpha levels.

Per Taggart colleague's recommendation [32], the Rubric for Assessing Interactive Qualities in Distance Courses was reviewed by 42 distance instructors, and their feedback was used to improve the clarity and comprehensiveness of rubric elements [1]. In the current study, students in four classes in two universities 
used it as part of post-course evaluations. To make comparisons more consistent, the post-course evaluation instrument usually used at University \#1 was used for all courses. This evaluation had two major parts: Part I focused on the instructor; Part II focused on other aspects of the course. Also, students were asked if this was their first online course and their preferred delivery system (online, face-to-face, combination, no preference, or other), and they were allowed to make open-ended comments. For the course at University \#1, evaluation materials were mailed to students with a self-addressed, stamped envelope. For courses in University \#2, evaluations were administered during the final (face-to-face) class period. In all cases, evaluation results were received anonymously.

One of the four courses in the study was completely online; students and instructor never met, and all interaction took place in asynchronous activities in a web-based course space. Other courses had limited face-to-face interaction (first and last classes meetings in one course, four sessions in the other), with 80$90 \%$ of course activities being done online in asynchronous activities in a web-based course space. The final course met face-to-face only twice but had weekly synchronous (videoconferencing) and asynchronous (web-based course space) activities. Table 1 summarizes these course characteristics.

\begin{tabular}{|l|l|l|}
\hline Location & Course Content & Delivery Characteristics \\
\hline Course \#1 & Web-based Design and Pedagogy & $100 \%$ asynchronous web-based activities \\
\hline Course \#2 & Educational Research Methods & $\begin{array}{l}80 \% \text { asynchronous web-based activities; 20\% face- } \\
\text { to-face }\end{array}$ \\
\hline Course \#3 & $\begin{array}{l}\text { Administration of Instructional } \\
\text { Technology }\end{array}$ & $\begin{array}{l}50 \% \text { asynchronous web-based activities; } 40 \% \\
\text { synchronous videoconferencing; 10\% face-to-face }\end{array}$ \\
\hline Course \#4 & Integrating Educational Technology & $\begin{array}{l}\text { 90\% asynchronous web-based activities; } 10 \% \text { face- } \\
\text { to-face }\end{array}$ \\
\hline
\end{tabular}

Table 1. Characteristics of Courses in the Study

Of the 92 students who took the courses, 71 agreed to complete the rubric as part of the post-course evaluation activity. Of completed post-course evaluations, 68 (74\%) had usable data. The numbers of students and completed evaluations in each course are shown in Table 2.

\begin{tabular}{|l|c|c|}
\hline Course & $\begin{array}{c}\text { Enrolled } \\
\text { (N) }\end{array}$ & $\begin{array}{c}\text { Usable } \\
\text { Evaluations }\end{array}$ \\
\hline & & \\
\hline Course \#1 & 28 & 13 \\
\hline Course \#2 & 16 & 12 \\
\hline Course \#3 & 23 & 20 \\
\hline Course \#4 & 25 & 23 \\
\hline Totals & 92 & $68(74 \%)$ \\
\hline
\end{tabular}

Table 2. Numbers of Students Enrolled and Completing Evaluations

\section{DATA ANALYSES AND RESULTS}

Three kinds of analyses were done to explore the rubric's reliability and validity as a measure of interaction across various kinds of distance courses and to examine the possible contributions of various elements of interaction to total course interaction. These included calculating the following: alpha levels across ratings in each of the four courses, correlations between overall rubric scores and course evaluation 
scores, and correlations between scores on rubric elements and course evaluation scores. Additional correlations were done between student characteristics (distance learning experience and course format preferences) and course ratings, to gather evidence of whether these affected students' perceptions of course quality or interaction levels. Finally, student comments were analyzed to gain further insights on student perceptions of courses' interactive qualities and the importance of interaction to course quality.

\section{A. Reliability Levels}

Using the strategy recommended by Baker and Abedi [33] to determine the level of inter-rater reliability of rubrics, Chronbach's alpha levels were calculated across rubric scores within each online course. For Courses \#1-\#4, these were: .88, .64, .93, and .95. These results indicate high consistency of ratings across student raters within each course.

\section{B. Correlations Between Rubric Scores and Course Evaluation Scores}

To obtain indications of the rubric's concurrent validity, Pearson correlations were done between the rubric scores and the post-course evaluation scores in each course. These results are shown in Table 3. All correlations were found to be significant at the levels shown in the table.

\begin{tabular}{|l|c|}
\hline & $\begin{array}{c}\text { Correlations Between Total Course } \\
\text { Evaluations and Rubric Scores } \\
(\delta)\end{array}$ \\
\hline & \\
\hline Course \#1 (N=13) & $.630^{* *}$ \\
\hline Course \#2 (N=12) & $.720^{*}$ \\
\hline Course \#3 (N=20) & $.643^{*}$ \\
\hline Course \#4 (N=23) & $.475^{*}$ \\
\hline \multicolumn{2}{|c|}{$* \mathbf{p}<.01$} \\
\hline
\end{tabular}

Table 3. Correlations Between Course Evaluation Scores and Rubric Scores Within Courses

Correlations also were done between rubric scores and Part I and Part II post-course evaluation subscores, across courses, and between rubric scores and the total scores on the post-course evaluations across courses. Also, to examine the contribution of each kind of interaction to total course interaction and help determine whether or not certain types of interaction seemed more related to course satisfaction, correlations were done between each rubric element and the total post-course evaluation scores. These data are shown in Table 4.

All correlations were found to be significant at the levels shown in the table. The highest correlations were observed between evaluation scores and Element \#4: Student engagement. Lowest correlations were on Element \#3: Technology interactivity. Overall correlations were fairly high, with total evaluation score correlating with total rubric score at .641 $(\mathrm{p}<.01)$. 


\begin{tabular}{|l|c|c|c|}
\hline & $\begin{array}{c}\text { Correlation } \\
\text { With Instructor } \\
\text { Evaluation } \\
\text { Sub-scores } \\
(\boldsymbol{\delta}) \\
\mathbf{( N = 6 8 )}\end{array}$ & $\begin{array}{c}\text { Correlation } \\
\text { With Other } \\
\text { Course Aspects } \\
\text { Sub-scores } \\
(\delta)\end{array}$ & $\begin{array}{c}\text { Correlation } \\
\text { With Total } \\
\text { Evaluation } \\
\text { Scores } \\
(\delta)\end{array}$ \\
\hline Total Rubric Scores Across Courses & $.592^{*}$ & $.640^{*}$ & $.641^{*}$ \\
\hline Rubric Element \#1: Social/Rapport Building & $.326^{*}$ & $.436^{*}$ & $.419^{*}$ \\
\hline Rubric Element \#2: Instructional designs & $.341^{*}$ & $.431^{*}$ & $.420^{*}$ \\
\hline Rubric Element \#3: Technology interactivity & $.311^{*}$ & $.279^{* *}$ & $.299^{* *}$ \\
\hline Rubric Element \#4: Student engagement & $.616^{*}$ & $.578^{*}$ & $.608^{*}$ \\
\hline Rubric Element \#5: Instructor engagement & $.397^{*}$ & $.435^{*}$ & $.440^{*}$ \\
\hline
\end{tabular}

$* \mathbf{p}<.01 \quad * * \mathbf{p}<.05$

Table 4. Correlations between course evaluation scores, subscores, and rubric scores

\section{Correlations Between Student Characteristics and Course Ratings}

Correlations also were done between scores on course evaluations, rubric ratings, and students' experience in distance courses (i.e., item asking “first course or not?") to determine whether students' assessment of interaction or overall course quality was related to their experience as distance learners. Similarly, correlations were done between the evaluation results and their preference of learning format (online, face-to-face, combination, no preference, or other) to determine if their assessment was related to course format preference. No significant correlations were found between any of these variables.

\section{Qualitative Analysis of Student Comments}

This analysis was intended to provide more insight into student perceptions of each course's interactive qualities and of the importance of interaction to overall course quality. Approximately $40 \%$ of the students (27 of the 68) offered comments, but all were fairly terse. Most were complimentary, and only a few offered any information helpful to the purpose of this study. The latter expressed a desire for more direction from the instructor, especially for how they were to use the various components of the online format. These comments had benefit primarily as formative feedback to instructors on ways they could improve their courses.

\section{INTERPRETATION AND CONCLUSIONS}

Results received to date from uses of the rubric in online or mostly-online courses reflected a fairly high correlation between post-course evaluations and rubric scores, indicating good concurrent validity. Although all correlations were significant, Element \#4 (evidence of student engagement) exhibited the highest correlations with the overall course evaluation and with certain components of post-course evaluations. One of the most interesting findings is that technology interactivity (Element \#3) correlates with overall evaluations of course quality less than any other aspect of the course. This could indicate that the actual technologies used are less important than instructor and student engagement and the ways activities are designed to promote social rapport and enhance learning.

High inter-rater reliabilities on rubric scores in all courses indicate that results are consistent across students who use the rubric to rate interactive qualities. To decrease variations in students' understanding 
of the rubric's purpose and meaning and to help accomplish the "training" in instrument use, that Taggart, Phifer, Nixon, \& Wood [32] indicate, is important to insure a rubric is used as the developers intended. The authors recommend giving students a set of written directions that has been developed to communicate the purpose of the rubric and what each element measures. Instructors can read these directions aloud and answer any questions students may have before they complete their assessment.

As Roblyer and Wiencke [1] indicate, a rubric which is a valid, reliable measure of various aspects of interaction in distance courses can be used to encourage interaction by students and instructors, as well as to measure how much students perceive it has occurred in given courses. It can also provide valuable feedback for instructors seeking to improve the quality of their online courses. This study used methods employed previously for other kinds of rubrics to help validate the usefulness of these non-traditional, but increasingly popular, instruments.

The results from this study provide further, though still tentative, evidence that the rubric designed to assess interactive qualities is a valid and reliable measure of one important aspect of distance courses. If its usefulness is established in additional courses and larger samples, such an instrument can help further both the design and research of optimal distance learning environments by helping to define and quantify observed interaction and allow empirical assessments of its contributions to course effectiveness.

\section{REFERENCES}

1. Roblyer, M. D., \& Wiencke, W. R. Design and Use of a Rubric to Assess and Encourage Interactive Qualities In Distance Courses. The American Journal of Distance Education 17(2): 77-97, 2003.

2. Gilbert, L., \& Moore, D. R. Building Interactivity Into Web Courses: Tools For Social And Instructional Interaction. Educational Technology 38(3): 29-35, 1998.

3. Moore, M. Three Types Of Interaction. The American Journal of Distance Education 3(2): 1989. Available online: http://www.ed.psu.edu/acsde/ajde/ed32.asp.

4. Vrasidas, C., and McIsaac, M. S. Factors Influencing Interaction In An Online Course. The American Journal of Distance Education 13(3): 22-36, 1999.

5. Wagner, E. D. In Support Of A Functional Definition Of Interaction. American Journal of Distance Education 8(2): 6-29, 1994.

6. Wagner, E. D. Interactivity: From Agents To Outcomes. New Directions for Teaching and Learning 71: 19-26, 1997.

7. Yacci, M. Interactivity Demystified: A Structural Definition For Distance Education And Intelligent Computer-Based Instruction. Educational Technology 40(4): 5-16, 2000.

8. Fulford, C. P., and Zhang, S. Perceptions Of Interaction: The Critical Predictor In Distance Education. American Journal of Distance Education 7(3): 8-21, 1993.

9. Zhang, S. and Fulford, C. P. Are Interaction Time And Psychological Interactivity The Same Thing In The Distance Learning Television Classroom? Educational Technology 34(6): 58-64, 1994.

10. Zirkin, B. G., and Sumler, D. E. Interactive Or Non-Interactive? That Is The Question!!! An annotated bibliography. Journal of Distance Education 10(1): 95-112, 1995.

11. Swan, K. Virtual Interaction: Design Factors Affecting Student Satisfaction and Perceived Learning in Asynchronous Online Courses. Distance Education 22(2): 306-331, 2001.

12. Waits, T., Lewis, L., and Greene, B. Distance Education At Degree-Granting Postsecondary Institutions. Washington, DC: National Center for Education Statistics. July, 2003. Available online: http://nces.ed.gov/pubsearch/pubsinfo.asp?pubid=2003017.

13. Durden, W. Liberal Arts for All, Not Just the Rich. Chronicle of Higher Education. Washington, DC, October 19, 2001. Available online: http://chronicle.com. 
14. Jonassen, D., Peck, K., and Wilson, B. Learning With Technology: A Constructivist Perspective. Columbus, Ohio: Prentice Hall/Merrill, 1999.

15. Goldsby, D., and Fazal, M. Now That Your Students Have Created Web-based Digital Portfolios, How do You Evaluate Them? Journal of Technology and Teacher Education 9(4): 607-616, 2001.

16. Chenau, J. Cyber Traveling Through the Loire Valley. Learning and Leading with Technology, 28(2): 22-27, 2000.

17. Picciano, A. Distance Learning: Making Connections Across Virtual Time and Space. Upper Saddle River, NJ: Merrill, Prentice Hall, 2001.

18. Wolcott, L. Distant, But Not Distanced. A Learner-Centered Approach To Distance Education. Techtrends 41(4): 23-27, 1996.

19. Hamza, M. K., and Alhalabi, B. Touching Students' Minds In Cyberspace. Learning and Technology 26(6): 36-39, 1999.

20. Hirumi, A., and Bermudez, A. Interactivity, Distance Education, And Instructional Systems Design Converge On The Information Superhighway. Journal of Research on Computing in Education 29(1): 1-16, 1996.

21. Hughes, C., and Hewson, L. Online Interaction: Developing A Neglected Aspect Of The Virtual Classroom. Educational Technology 38(4): 48-55, 1998.

22. Kimeldorf, M. Teaching Online-Techniques And Methods. Learning and Leading With Technology 23(1): 26-30, 1995.

23. Klemm, W. Eight Ways To Get Students More Engaged In Online Conferences. T.H.E. Journal 26(1): 62-64, 1998.

24. Simonson, M., Smaldino, S. Albright, M., and Zvacek, S. Teaching And Learning At A Distance: Foundations Of Distance Education. Upper Saddle River, NJ: Merrill, Prentice Hall, 2000.

25. Horn, D. Distance Education: Is Interactivity Compromised? Performance and Instruction 33(9): 1215, 1994.

26. Kearsley, G. Learning And Teaching In Cyberspace. Toronto, Ontario: Wadsworth, Thompson Learning, 2000.

27. Solloway, S., and Harris, E. Creating Community Online. Educom Review 34(2): 1999. Available online: http://www.educause.edu/ir/library/html/erm99021.html.

28. Moore, M., and Kearsley, G. Distance Education: A Systems View. Belmont, CA: Wadsworth Publishing Company, 1996.

29. Hillman, D. C. A., Willis, E. J, and Gunawardena, C. Learner-Interface Interaction In Distance Education: An Extension Of Contemporary Models And Strategies For Practitioners. American Journal of Distance Education 8(2): 30-42, 1994.

30. Brown, R. The Process Of Community-Building In Distance Learning Classes. Journal of Asynchronous Learning Networks 5(2): September 2001. Available online: http://www.sloan-c.org/publications/jaln/v5n2/v5n2 brown.asp.

31. Roblyer, M. A Rubric To Encourage And Assess Student Engagement In Online Course Conferences. Paper presented at the Society for Information Technology in Teacher Education (SITE) Annual Conference, Nashville, Tennessee, March 2002.

32. Taggart, G., Phifer, S., Nixon, J., and Wood, M. Rubrics: A Handbook For Construction And Use. Lanham, MD: Scarecrow Press, 2001.

33. Baker, E. L., and Abedi, J. Dimensionality and Generalizability of Domain-independent Performance Assessments. Journal of Educational Research 89(4): 197-205, March-April 1996.

34. Novak, J. R., Herman, J. L., and Gearhart, M. L. Establishing Validity for Performance-based Assessments: An Illustration for Collections of Student Writing. Journal of Educational Research 89(4): 220-233, March-April 1996.

\section{ACKNOWLEDGEMENTS}

The authors wish to thank colleague Jon C. Marshall, who contributed many helpful insights to the 
development of the AERA paper on which this article was based.

\section{ABOUT THE AUTHORS}

M. D. Roblyer has been a Professor of Educational Technology in higher education institutions since 1982 and is currently Adjunct Professor for the University of Maryland University College (UMUC), Graduate School of Management and Technology. She teaches courses online in UMUC's graduate degree programs and authors textbooks on integrating technology into teaching. Professional interests include the design of computer-based and distance learning materials for $\mathrm{K}-12$ and higher education. Research interests include identifying factors that contribute to student success in Virtual High Schools and exploring ways to increase interactive qualities in distance courses.

William R. Wiencke is Associate Professor of Educational Technology for the University of West Georgia, College of Education. He teaches both face-to-face and online courses in instructional technology, diffusion of innovations, and integrating technology in the curriculum. Research interests include uses and impact of emerging technologies in society and education.

\section{APPENDIX A \\ RUBRIC FOR ASSESSING INTERACTIVE QUALITIES IN DISTANCE COURSES (C) 2004, M. D. ROBL YER)}

RUBRIC DIRECTIONS: The rubric shown below has five (5) separate elements that contribute to a course's level of interaction and interactivity. For each of these five elements, circle a description below it that applies best to your course. After reviewing all elements and circling the appropriate level, add up the points to determine the course's level of interactive qualities (e.g., low, moderate, or high)

\begin{tabular}{|l|l|}
\hline Low interactive qualities & $1-9$ points \\
\hline Moderate interactive qualities & $10-17$ points \\
\hline High interactive qualities & $18-25$ points \\
\hline
\end{tabular}

\begin{tabular}{|c|c|c|c|c|c|}
\hline $\begin{array}{l}\text { Scale } \\
\text { (see points } \\
\text { below) }\end{array}$ & $\begin{array}{l}\text { Element \#1: } \\
\text { Social/Rapport- } \\
\text { building Designs } \\
\text { for Interaction }\end{array}$ & $\begin{array}{l}\text { Element \#2: } \\
\text { Instructional } \\
\text { Designs for } \\
\text { Interaction }\end{array}$ & $\begin{array}{l}\text { Element \#3: } \\
\text { Interactivity of } \\
\text { Technology } \\
\text { Resources }\end{array}$ & $\begin{array}{l}\text { Element \#4: } \\
\text { Evidence of } \\
\text { Learner } \\
\text { Engagement }\end{array}$ & $\begin{array}{l}\text { Element \#5: } \\
\text { Evidence of } \\
\text { Instructor } \\
\text { Engagement }\end{array}$ \\
\hline $\begin{array}{l}\text { Low } \\
\text { interactive } \\
\text { qualities } \\
\text { (1 point each) }\end{array}$ & $\begin{array}{l}\text { The instructor does } \\
\text { not encourage } \\
\text { students to get to } \\
\text { know one another on } \\
\text { a personal basis. No } \\
\text { activities require } \\
\text { social interaction, or } \\
\text { are limited to brief } \\
\text { introductions at the } \\
\text { beginning of the } \\
\text { course. }\end{array}$ & $\begin{array}{l}\text { Instructional activities } \\
\text { do not require two- } \\
\text { way interaction } \\
\text { between instructor } \\
\text { and students; they call } \\
\text { for one-way delivery } \\
\text { of information (e. g., } \\
\text { instructor lectures, } \\
\text { text delivery) and } \\
\text { student products } \\
\text { based on the } \\
\text { information. }\end{array}$ & $\begin{array}{l}\text { Fax, web pages, or } \\
\text { other technology } \\
\text { resource allows one- } \\
\text { way delivery of } \\
\text { information (text } \\
\text { and/or graphics). }\end{array}$ & $\begin{array}{l}\text { By end of course, } \\
\text { most students (50- } \\
75 \% \text { ) are replying to } \\
\text { messages from the } \\
\text { instructor, but only } \\
\text { when required; } \\
\text { messages are } \\
\text { sometimes } \\
\text { unresponsive to topics } \\
\text { and tend to be either } \\
\text { brief or wordy and } \\
\text { rambling. }\end{array}$ & $\begin{array}{l}\text { Instructor responds } \\
\text { only randomly to } \\
\text { student queries; } \\
\text { responses usually } \\
\text { take more than } 48 \\
\text { hours; feedback is } \\
\text { brief and provides } \\
\text { little analysis of } \\
\text { student work or } \\
\text { suggestions for } \\
\text { improvement. }\end{array}$ \\
\hline $\begin{array}{l}\text { Minimum } \\
\text { interactive } \\
\text { qualities } \\
\text { ( } 2 \text { points each) }\end{array}$ & $\begin{array}{l}\text { In addition to brief } \\
\text { introductions, the } \\
\text { instructor requires } \\
\text { one other exchange } \\
\text { of personal } \\
\text { information among } \\
\text { students, e.g., }\end{array}$ & $\begin{array}{l}\text { Instructional activities } \\
\text { require students to } \\
\text { communicate with the } \\
\text { instructor on an } \\
\text { individual basis only } \\
\text { (e. g., } \\
\text { asking/responding to }\end{array}$ & $\begin{array}{l}\text { E-mail, listserv, } \\
\text { conference/bulletin } \\
\text { board or other } \\
\text { technology resource } \\
\text { allows two-way, } \\
\text { asynchronous } \\
\text { exchanges of }\end{array}$ & $\begin{array}{l}\text { By end of course, } \\
\text { most students ( } 50- \\
75 \% \text { ) are replying to } \\
\text { messages from the } \\
\text { instructor and other } \\
\text { students, both when } \\
\text { required and on a }\end{array}$ & $\begin{array}{l}\text { Instructor responds } \\
\text { to most student } \\
\text { queries; responses } \\
\text { usually are within } \\
48 \text { hours; feedback } \\
\text { sometimes offers } \\
\text { some analysis of } \\
\end{array}$ \\
\hline
\end{tabular}




\begin{tabular}{|c|c|c|c|c|c|}
\hline & $\begin{array}{l}\text { written bio of } \\
\text { personal background } \\
\text { and experiences. }\end{array}$ & instructor questions). & $\begin{array}{l}\text { information (text and } \\
\text { graphics). }\end{array}$ & $\begin{array}{l}\text { voluntary basis; } \\
\text { replies are usually } \\
\text { responsive to topics } \\
\text { but often are either } \\
\text { brief or wordy and } \\
\text { rambling. }\end{array}$ & $\begin{array}{l}\text { student work and } \\
\text { suggestions for } \\
\text { improvement. }\end{array}$ \\
\hline $\begin{array}{l}\text { Moderate } \\
\text { interactive } \\
\text { qualities } \\
\text { ( } 3 \text { points each) }\end{array}$ & $\begin{array}{l}\text { In addition to } \\
\text { providing for } \\
\text { exchanges of } \\
\text { personal information } \\
\text { among students, the } \\
\text { instructor provides at } \\
\text { least one other in- } \\
\text { class activity } \\
\text { designed to increase } \\
\text { communication and } \\
\text { social rapport among } \\
\text { students. }\end{array}$ & $\begin{array}{l}\text { In addition to the } \\
\text { requiring students to } \\
\text { communicate with the } \\
\text { instructor, } \\
\text { instructional activities } \\
\text { require students to } \\
\text { communicate with } \\
\text { one another (e. g., } \\
\text { discussions in pairs or } \\
\text { small groups). }\end{array}$ & $\begin{array}{l}\text { In addition to } \\
\text { technologies used for } \\
\text { two-way } \\
\text { asynchronous } \\
\text { exchanges of } \\
\text { information, } \\
\text { chatroom, or other } \\
\text { technology allows } \\
\text { synchronous } \\
\text { exchanges of } \\
\text { primarily written } \\
\text { information. }\end{array}$ & $\begin{array}{l}\text { By end of course, all } \\
\text { or nearly all students } \\
\text { (90-100\%) are } \\
\text { replying to messages } \\
\text { from the instructor } \\
\text { and other students, } \\
\text { both when required } \\
\text { and voluntarily; } \\
\text { replies are always } \\
\text { responsive to topics } \\
\text { but sometimes are } \\
\text { either brief or wordy } \\
\text { and rambling. }\end{array}$ & $\begin{array}{l}\text { Instructor responds } \\
\text { to all student } \\
\text { queries; responses } \\
\text { usually are within } \\
48 \text { hours; feedback } \\
\text { usually offers some } \\
\text { analysis of student } \\
\text { work and } \\
\text { suggestions for } \\
\text { improvement. }\end{array}$ \\
\hline $\begin{array}{l}\text { Above average } \\
\text { interactive } \\
\text { qualities } \\
\text { (4 points each) }\end{array}$ & $\begin{array}{l}\text { In addition to } \\
\text { providing for } \\
\text { exchanges of } \\
\text { personal information } \\
\text { among students and } \\
\text { encouraging } \\
\text { communication and } \\
\text { social interaction, } \\
\text { the instructor also } \\
\text { interacts with } \\
\text { students on a } \\
\text { social/personal basis. }\end{array}$ & $\begin{array}{l}\text { In addition to the } \\
\text { requiring students to } \\
\text { communicate with the } \\
\text { instructor, } \\
\text { instructional activities } \\
\text { require students to } \\
\text { develop products by } \\
\text { working together } \\
\text { cooperatively (e.g., in } \\
\text { pairs or small groups) } \\
\text { and sharing feedback. }\end{array}$ & $\begin{array}{l}\text { In addition to } \\
\text { technologies used for } \\
\text { two-way synchronous } \\
\text { and asynchronous } \\
\text { exchanges of written } \\
\text { information, } \\
\text { additional } \\
\text { technologies (e. g., } \\
\text { teleconferencing) } \\
\text { allow one-way visual } \\
\text { and two-way voice } \\
\text { communications } \\
\text { between instructor } \\
\text { and students. }\end{array}$ & $\begin{array}{l}\text { By end of course, } \\
\text { most students (50- } \\
75 \% \text { ) are both } \\
\text { replying to and } \\
\text { initiating messages } \\
\text { when required and } \\
\text { voluntarily; messages } \\
\text { are detailed and } \\
\text { responsive to topics, } \\
\text { and usually reflect an } \\
\text { effort to communicate } \\
\text { well. }\end{array}$ & $\begin{array}{l}\text { Instructor responds } \\
\text { to all student } \\
\text { queries; responses } \\
\text { usually are prompt, } \\
\text { i.e., within } 24 \\
\text { hours; feedback } \\
\text { always offers } \\
\text { detailed analysis of } \\
\text { student work and } \\
\text { suggestions for } \\
\text { improvement }\end{array}$ \\
\hline $\begin{array}{l}\text { High level of } \\
\text { interactive } \\
\text { qualities } \\
\text { ( } 5 \text { points each) }\end{array}$ & $\begin{array}{l}\text { In addition to } \\
\text { providing for } \\
\text { exchanges of } \\
\text { information and } \\
\text { encouraging student- } \\
\text { student and } \\
\text { instructor-student } \\
\text { interaction, the } \\
\text { instructor provides } \\
\text { ongoing course } \\
\text { structures designed } \\
\text { to promote social } \\
\text { rapport among } \\
\text { students and } \\
\text { instructor. }\end{array}$ & $\begin{array}{l}\text { In addition to the } \\
\text { requiring students to } \\
\text { communicate with the } \\
\text { instructor, } \\
\text { instructional activities } \\
\text { require students to } \\
\text { develop products by } \\
\text { working together } \\
\text { cooperatively (e.g., in } \\
\text { pairs or small groups) } \\
\text { and share results and } \\
\text { feedback with other } \\
\text { groups in the class. }\end{array}$ & $\begin{array}{l}\text { In addition to } \\
\text { technologies to allow } \\
\text { two-way exchanges of } \\
\text { text information, } \\
\text { visual technologies } \\
\text { such as two-way } \\
\text { video or } \\
\text { videoconferencing } \\
\text { technologies allow } \\
\text { synchronous voice \& } \\
\text { visual } \\
\text { communications } \\
\text { between instructor } \\
\text { and students and } \\
\text { among students. }\end{array}$ & $\begin{array}{l}\text { By end of course, all } \\
\text { or nearly all students } \\
(90-100 \%) \text { are both } \\
\text { replying to and } \\
\text { initiating messages, } \\
\text { both when required } \\
\text { and voluntarily; } \\
\text { messages are detailed, } \\
\text { responsive to topics, } \\
\text { and are well- } \\
\text { developed } \\
\text { communications. }\end{array}$ & $\begin{array}{l}\text { Instructor responds } \\
\text { to all student } \\
\text { queries; responses } \\
\text { are always prompt, } \\
\text { i.e. within } 24 \\
\text { hours; feedback } \\
\text { always offers } \\
\text { detailed analysis of } \\
\text { student work and } \\
\text { suggestions for } \\
\text { improvement, } \\
\text { along with } \\
\text { additional hints and } \\
\text { information to } \\
\text { supplement } \\
\text { learning. }\end{array}$ \\
\hline Total each: & pts. & pts. & pts. & pts. & pts. \\
\hline Total overall: & pts. & & & & \\
\hline
\end{tabular}

Permission is granted to use this instrument, either in paper or electronic form, under the following conditions: (1) the purpose is nonprofit research or education; (2) any research summary based on the instrument use cites the research report published in the 2004 article in the Journal of Asynchronous Learning Networks entitled "Exploring the Interaction Equation: Validating a Rubric to Assess and Encourage Interaction in Distance Courses" by Roblyer and Wiencke; and (3) the instrument itself is used in its complete form and displays the following statement: 
Copyright (C 2004, M. D. Roblyer (mroblyer@polaris.umuc.edu). Used by blanket permission of the author for nonprofit research and/or education only. For other permission, contact the author.

For information or other permissions, contact the author at: mroblyer@polaris.umuc.edu 

